\title{
THE USE OF VOCALIZATION SIGNALS TO ESTIMATE THE LEVEL OF PAIN IN PIGLETS
}

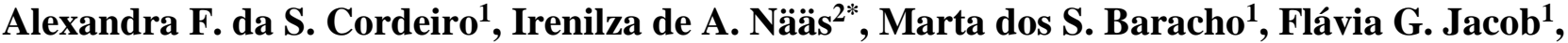 \\ Daniella J. de Moura ${ }^{1}$
}

${ }^{2 *}$ Corresponding author. Faculdade de Engenharia Agrícola, UNICAMP/ Campinas - SP, Brasil. E-mail: irenilza@gmail.com

\section{KEYWORDS}

stress, caudectomy, castration, marking, swine, sound signals.

\begin{abstract}
Pain is considered a condition that most affect the welfare of animals and its measurement is seen as a difficult task. This research aimed to determine the level of pain in pigs by their vocalization. It was recorded the vocalizations of 20 male piglets under normal circumstances (I), marking by Australian method (II), tail trimming management (III), and castration (IV). A unidirectional microphone and a digital recorder were used to record the sound signals. The results suggested that Pitch frequency $(\mathrm{Hz})$, the maximum amplitude $(\mathrm{Pa})$, and intensity $(\mathrm{dB})$ increased from pain-free pigs to the marking procedure; and from marking to both tail trimming and castration The tail trimming and castration vocal response did not differ.
\end{abstract}

\section{INTRODUCTION}

Pork is the most consumed meat in the world (SI, 2017), and Brazil is a significant exporter. Animal welfare is one of the critical demands of the international meat market. However, applied studies are yet needed for consolidating its application in pig farming. Animal welfare is an ethical issue that is an increasing demand by consumers (Veloni et al., 2013), besides being associated with the animal productivity and meat quality (Dawkins, 2016). Pain is one of the leading factors that affect the animal well-being, and to determine its intensity is a difficult task even for humans. Pigs are exposed to some aggressive management methods that produce pain, such as the tail trimming (caudectomy), castration, and the cutting of teeth (Duncan, 2005), which are standard procedures in the production cycle on commercial farms. Marchant et al. (2009) evaluated alternative methods to the painful process such as the tail trimming, marking, and castration. Immune castration is an alternative to usual castration nowadays often used to alleviate the pain in pigs (Martins, et al., 2013; Bruno et al., 2013; Lucas et al., 2016). The use of anesthetics to decrease the pain caused by these procedures might be a good alternative (Bates et al., 2014; Herskin et al., 2016; Bonastre et al., 2016).

The castration of pigs is carried out to avoid undesirable taste and odor in the meat (Martins et al., 2013). Castration is standard practice, and it is usually performed without anesthesia; likewise, tail trimming, which is farm management to prevent cannibalism. The identification of pigs is essential for product traceability.
Furthermore, the Australian method for pig marking is one of the most used technique worldwide, consisting in a piercing attached to the pig ear for the identification (Sobestiansky et al., 1998). The vocalization has been suggested as a useful method for estimating the welfare of pigs (Moi et al., 2015; Marx et al., 2003; Leidig et al. 2009). It is a non-invasive technique that provides information about the status of the animal. It is possible to recognize physiological changes by analyzing the frequency of voice signals (Johnson et al. 1994). An increase in the rate of vocalization was observed in pigs after receiving corticotrophin injection, the stress hormone (Johnson et al. 1994). Furthermore, castrated piglets without anesthesia emitted a stress call during $50.8 \%$ of the total procedure time, while that using local anesthesia emitted stress vocalization in $30.7 \%$ of the time (Leidig et al., 2009).

Techniques to determine pain and welfare in farmed animals might be well understood to avoid misinterpretation and get more accurate results to recognize the real status of the animal (Fitzpatrick et al., 2006). Machine-learning techniques including data mining improved the discovery of knowledge in the livestock production (Nääs et al., 2008; Moi et al., 2014; Pandorfi et al., 2011). Amongst the tasks of data mining, the classification allows the generation, starting from a set of examples (training), of a classifier able to classify a new sample in its class. The C4.5 algorithm is one of the most used in the classification task since it enables the illustration of the information acquired (Rezende, 2005).

${ }^{1}$ Faculdade de Engenharia Agrícola, UNICAMP/ Campinas - SP, Brasil. 
This algorithm has several implementations, among them, the J48 algorithm, implemented using Weka ${ }^{\circledR}$ (Freeware, The University of Waikato, New Zealand) computer program to generate decision trees.

The determination of the pain level in any living being is subjective and difficult to measure. However, estimating the degree of pain might help to identify its cause, and make available specific and faster treatment. This research aimed to assess the level of pain in farmed pigs by their vocalization during different pain management methods commonly adopted in the production cycle.

\section{MATERIAL AND METHODS}

The experiment took place in a commercial farm located in the county of Holambra-SP, Brazil. Latitude $22^{\circ}$ $37^{\prime} 60^{\prime \prime} \mathrm{S}, 47^{\circ} 3^{\prime} 23^{\prime \prime} \mathrm{W}$, and an altitude of $604 \mathrm{~m}$. Data collection was done in the morning with an average ambient temperature of $25.5{ }^{\circ} \mathrm{C}$ and relative humidity of $40.4 \%$. Vocalizations of 20 male piglets 7-days-old were recorded, under different conditions: (I) pain-free, (II) marking by cutting the ear (Australian process), (III) tail trimming management, and (IV) surgical castration. In all vocalization, records were done using each animal individually. The experimental procedure was approved by the Ethics Committee-UNICAMP, protocol no. 2224$1 \backslash 2011$.

For the pain-free scenario, the piglets were gently removed from their stalls and allocated in a corridor (Figure 1A), in which voice signal was recorded. For the extreme procedure scenarios, vocalizations recording were made during the farm management of tail trimming, marking and castration. These procedures were done in this order and without interval between them, as usual. The duration of the signal was the time the pigs vocalized during the process. The caudectomy was performed using a device for cutting with a hot iron. The castration carried out on males (Figure 1B) was done with a longitudinal incision on the scrotum to exteriorize the testicle, and then the spermatic cord was pulled out until its total rupture. After that, they were marked in the ears with notches and holes (Figure 1C).

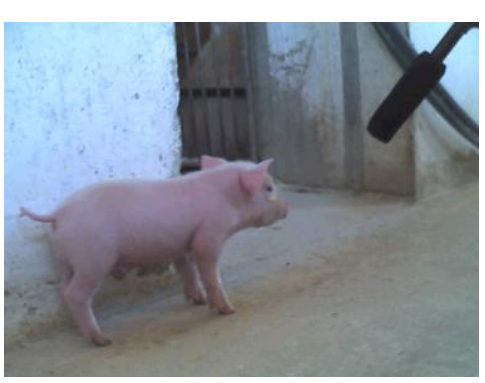

A

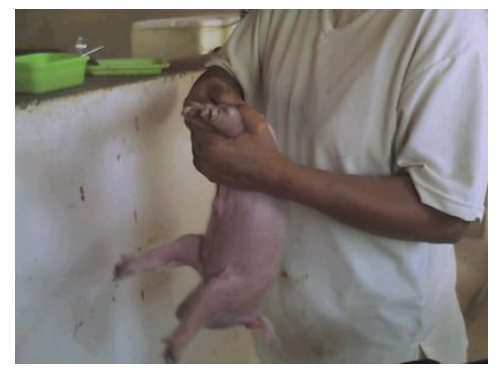

B

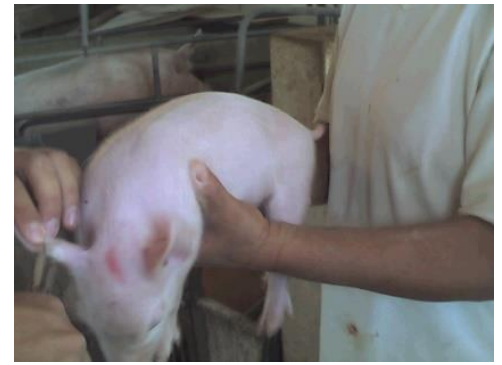

C

FIGURE 1. Collecting acoustic signal under standard conditions (A), marking the ear (B) and surgical castration (C).

A unidirectional microphone (Yoga ${ }^{\circledR}$ Electronics Co., Taipei, Taiwan) was positioned approximately $20 \mathrm{~cm}$ from the animals to record the acoustic signals, and a digital microphone recorder (Marantz ${ }^{\circledR}$ PMD 660) was used to digitalize the signals at a frequency of up to $44,100 \mathrm{~Hz}$. The signals were edited and analyzed using Praat ${ }^{\circledR}$ (Free software, University of Amsterdam, The Netherlands) obtaining six attributes of each acoustic signal (Table 1).

TABLE 1 . The summary of studied attributes, units, and description of the recorded signals.

\begin{tabular}{ccc}
\hline Attribute & Unit & Description \\
\hline Energy & $\mathrm{Pa}^{2} *_{\mathrm{s}}$ & Energy emitted by a sound wave \\
Maximum amplitude & $\mathrm{s}$ & Duration of the sound \\
Intensity & $\mathrm{Pa}$ & The maximum amplitude of the sound wave \\
Pitch & $\mathrm{dB}$ & The intensity of the sound wave \\
\end{tabular}


For comparing the recorded scenarios, ANOVA was applied to data, and mean values of each attribute were compared using Tukey test. For identifying pain conditions data was processed using the software Weka ${ }^{\circledR}$ 3.5 (Weka Freeware, The University of Waikato, New Zealand) using the algorithm of the decision tree C4.5, known as J48. Cross-validation was applied to $10 \%$ of samples. The statistical analysis was performed using Minitab $^{\circledR} 15$ software (Minitab Inc., Pennsylvania, USA).

\section{RESULTS AND DISCUSSION}

Table 2 shows ANOVA results for the four conditions evaluated. There was the statistical difference for all parameters $(p \leq 0.05)$. However, the duration of the signal was the only parameter that differed from all stressful situations. The length of the calls of the sound pig was higher ( 0.14 to $2.31 \mathrm{~s})$ than that of the pig with arthritis (0.15 to $1.88 \mathrm{~s}$ ) (Risi, 2010). These results differ from those in the present study in which the duration of the signal was lower when pigs were under management stress. Sound pigs had a signal duration of $0.264 \mathrm{~s}$ while marking of pigs led to a signal duration of $4.131 \mathrm{~s}$, tail trimming was $7.650 \mathrm{~s}$, and $13.035 \mathrm{~s}$ recorded during the castration.

The parameters Pitch frequency, maximum amplitude, and intensity presented similar behavior, tending to increase successively from pain-free to marking, and after tail trimming, and castration. That could be associated with pain on a scale from normal until de castration, which is referred to the highest pain level known in pigs (Tallet et al., 2013). Risi et al. (2010) found a lower intensity $(79.76 \mathrm{~dB})$ for sound pigs than animals affected by arthritis $(78.15 \mathrm{~dB})$. In the current study, the signal intensity was lower in the animals not exposed to painful management $(70.41 \mathrm{~dB})$ than that recorded during pig marking (77.64 dB), caudectomy (88.31 dB), and castration $(87.39 \mathrm{~dB})$.

TABLE 2. The results of the acoustic parameters (mean \pm standard deviation) in the four studied conditions (pain-free, identification/marking, tail trimming, and castration).

\begin{tabular}{lllll}
\hline & \multicolumn{4}{c}{ Stress condition } \\
\cline { 2 - 5 } Parameter & Pain-free & Marking & Caudectomy & Castration \\
\hline Energy $\left(\mathrm{Pa}^{2} * \mathrm{~s}\right)$ & $0.0138 \pm 0.0569 \mathrm{c}$ & $0.4122 \pm 0.453 \mathrm{c}$ & $2.1114 \pm 0.7735 \mathrm{~b}$ & $3.1262 \pm 1.4119 \mathrm{a}$ \\
Duration $(\mathrm{s})$ & $0.264 \pm 0.179 \mathrm{~d}$ & $4.131 \pm 1.604 \mathrm{c}$ & $7.650 \pm 1.964 \mathrm{~b}$ & $13.035 \pm 3.640 \mathrm{a}$ \\
Maximum amplitude $(\mathrm{Pa})$ & $0.2683 \pm 0.1081 \mathrm{c}$ & $0.7762 \pm 0.334 \mathrm{~b}$ & $1.000 \pm 0.000 \mathrm{a}$ & $1.0000 \pm 0.000 \mathrm{a}$ \\
Intensity $(\mathrm{dB})$ & $70.414 \pm 3.342 \mathrm{c}$ & $77.641 \pm 9.893 \mathrm{~b}$ & $88.309 \pm 1.878 \mathrm{a}$ & $87.394 \pm 1.821 \mathrm{a}$ \\
Pitch $(\mathrm{Hz})$ & $126.12 \pm 100.97 \mathrm{c}$ & $214.58 \pm 85.10 \mathrm{~b}$ & $330.97 \pm 77.20 \mathrm{a}$ & $285.01 \pm 73.82 \mathrm{a}$ \\
\hline
\end{tabular}

Numberger et al. (2016) evaluated the cortisol level in piglet subject to painful procedures and found that the cortisol response increased as the degree of pain imposed by the process (handling of the pig, marking tail trimming, and castration. Marchant et al. (2009) compared tail trimming using two methods cold and hot and found that hot caudectomy presented vocalization with higher frequency and duration than in the cold procedure. This result could be related to the different pain intensity from the use of different methods.

For these three parameters, there was no difference between tail trimming and castration. These results suggest that Pitch frequency, the maximum amplitude and signal intensity of the pig vocal increase as the pain level increases. Tallet et al. (2013) studied swine vocalization in different stress conditions and concluded that there is a clear relationship between the circumstances and the vocal expression. According to the authors, high-frequency calls and long duration are associated with situations involving risk of life.

The signal duration was different for the four process exposure with a gradual increase in normal, marking, tail trimming and castration. This result may be explained by the length of the procedure and not by the pain itself. According to Marchant et al. (2009), the time needed to perform the process may also result in the stress response. The signal of energy had a different behavior compared to the other parameters: normal handling did not differentiate from marking, but it did between tail trimming and castration. The duration of each method could explain these results, and the signal energy emitted was related to the length of the time the pig vocalized. Marx et al. (2003) found higher energy in the signals from screams than those from grunts. Some studies found that castrated piglets without anesthesia showed vocalization with higher energy compared to those animals with local anesthesia (White et al., 1995; Horn et al., 1999).

It was possible to classify stressful situations evaluated with $78.20 \%$ accuracy using only two vocalization parameters signal duration (s) and energy $\left(\mathrm{Pa}^{2}\right.$ * s). According to the decision tree (Figure 2), the signal duration is the most critical parameter to classify stress conditions, followed by signal energy. If the signal duration is $\leq 0.82 \mathrm{~s}$ the animal is in its normal state, stress-free, but if the signal duration is $>8.68$, the vocalization is from an animal during castration. If the length of the signal ranged between $0.817 \mathrm{~s}$ and $8.68 \mathrm{~s}$, then it should also consider the energy. In this case, if the energy is $\leq 1.41$, the situation is marking, and if it is $\geq$ 1.41 , then it refers to the tail trimming. 


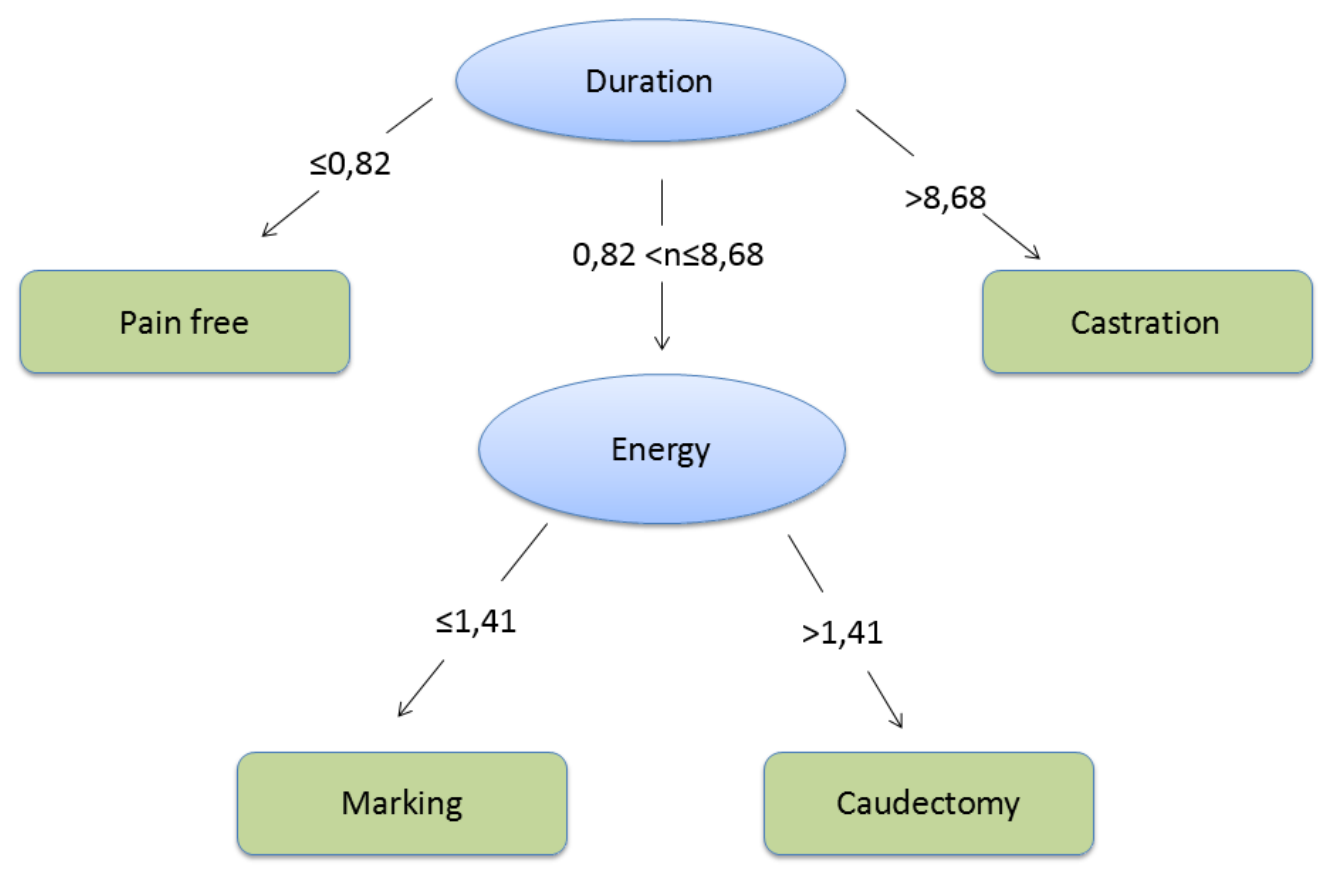

FIGURE 2. Decision tree generated by the algorithm J48 (Weka® software) for the signals duration and energy to classify the pig stress level (normal, marking, caudectomy or castration).

Marx et al. (2003) evaluated pigs' vocalization during castration and concluded that vocalization associated with pain could be identified and characterized mainly by energy, frequency, and duration of the signal. Several authors found a difference in the vocalization of animals subjected to a painful procedure, which suggests the possibility of estimating the level of pain by assessing their vocalization (Marx et al., 2003; Düpjan et al., 2008; Tallet et al., 2013). The vocal response of pigs submitted different levels of frustration and fear (Weary et al., 1998; Schön et al., 2001) be reliable indicators to estimate animal welfare (Manteuffel et al., 2004; Moi et al., 2015).

The vocalization is an outward response that may allow evaluating whether there are management problems (Fraser, 1974). The pig vocal response helps to identify the inherent risk of the lack of welfare at various stages of the typical farm management (White et al., 1995; Weary et al., 1998; Horn et al., 1999; Schön et al., 2001). Vocalization recording is also a valid method for understanding the impact of stress, pain, and discomfort in the animal's behavior.

Practical alternatives such as the development of more appropriate methods, local and general anesthetics, or the use of non-surgical methods (e.g., immune castration) (Martins et al., 2013; Bruno et al., 2013) should be designed to improve animal welfare. Barbieri et al. (2012) evaluated distinct methods of marking and concluded that using the RFID transponder in the perineum area is the adequate swine identifying process.

\section{CONCLUSIONS}

There are different acoustic parameters to help to evaluate the level of pain in piglet management, and the current study separated the response as pigs subject to pain and no pain. It was possible to determine the pain level in pigs subjected to different painful managements conditions that are part of typical pig farm production management.

\section{ACKNOWLEDGMENTS}

The authors wish to thank FAPESP, CAPES, and CNPq for granted scholarship.

\section{REFERENCES}

Bates JL, Karriker LA, Stock ML, Pertzborn KM, Baldwin LG, Wulf LW, Coetzee JF (2014) Impact of transmammary-delivered meloxicam on biomarkers of pain and distress in piglets after castration and tail docking. Plos One 9(12):e113678.

Barbieri S, Minero M, Barattiero D, Cantàfora AF, Crimella C (2012) Recognised-by-law versus other identification systems in pigs: piglets discomfort evaluation and performance testing. Italian Journal of Animal Science 11:190-195.

Bonastre C, Mitjana O, Tejedor MT, Calavia M, Yuste AG, Úbeda JL, Falceto MV (2016) Acute physiological responses to castration-related pain in piglets: the effect of two local anesthetics with or without meloxicam. Animal 10(09):1474-1481.

Bruno HV, Kiefer C, Brumatti RC, Dos Santos AP, Rocha GC, Rodrigues GP (2013) Avaliação técnico-econômica de suínos machos imuno e cirurgicamente castrados. Ciência Rural 43(11):2063-2069.

Dawkins MS (2016) Animal welfare and efficient farming: is conflict inevitable? Animal Production Science 57(2):201-208.

Duncan IJH (2005) Science-based assessment of animal welfare: farm animals. Scientific and Technical Review 24:483-492.

Düpjan S, Schön PC, Puppe B, Tuchscherer A, Manteuffel G (2008) Differential vocal responses to physical and mental stressors in domestic pigs (Sus scrofa). Applied Animal Behaviour Science 114:105-115. 
Fitzpatrick J, Scott M, Nolan A (2006) Assessment of pain and welfare in sheep. Small Ruminants Research 62:55-61.

Fraser D (1974) The vocalizations and other behaviour of growing pigs in an "open field" test. Applied Animal Ethology 1:3-16.

Herskin MS, Di Giminiani P, Thodberg K (2016) Effects of administration of a local anaesthetic and/or an NSAID and of docking length on the behaviour of piglets during $5 \mathrm{~h}$ after tail docking. Research in Veterinary Science 108:60-67.

Horn T, Marx G, von Borell E (1999) Castration of male piglets (I): Aspects of animal welfare and methods of anesthesia Dtsch Tierarztl Wochenschr 106:271-274.

Johnson RW, Von Borell E, Anderson LL, Kojic LD, Cunnick E (1994) Intracerebroventricular injection of corticotrophin-releasing hormone in the pig: acute effects on behavior, adrenocorticotropin secretion, and immunosuppression. Endocrinology 135:642-648.

Leidig MS, Hertrampf B, Failing K, Schumann A, Reiner G (2009) Pain and discomfort in male piglets during surgical castration with and without local anesthesia as determined by vocalization and defense behaviour. Applied Animal Behaviour Science 116:174-178.

Lucas DS, Siqueira ETF, Haguiwara MMH, Azevedo SS, Yotsuyanagi SE, Silva TJP, Soto FRM (2016) Effect of piglet castration with nonsurgical sterilant on the zootechnical performance and pork carcass quality. Arquivo Brasileiro de Medicina Veterinária e Zootecnia 68(6):1487-1496.

Marchant JN, Lay Jr DC, McMunn KA, Cheng HW, Pajor EA, Marchant-Forde RM (2009) Postnatal piglet husbandry practices and well-being: The effects of alternative techniques delivered separately. Journal of Animal Science 87:1479-1492.

Marx G, Horn T, Thielebein J, Knubel B, Borell E (2003) Analysis of pain-related vocalization in young pigs. Journal of Sound and Vibration 266:687-698.

Martins PC, Albuquerque MD, Machado IP, Mesquita AA (2013) Implicações da imunocastração na nutrição de suínos e nas características de carcaça. Archivos de Zootecnia 62:105-118.

Manteuffel G, Puppe B, Schoon PC (2004) Vocalization of farm animals as a measure of welfare. Applied Animal Behaviour Science 88:163-182. DOI:

http://dx.doi.org/10.1016/j.applanim.2004.02.012

Moi M, Nääs IA, Caldara FR, Paz ICLA, Garcia RG, Cordeiro AFS, Seno LO (2015) Vocalization as a welfare indicative for pigs subjected to stress situations. Arquivo Brasileiro de Medicina Veterinária e Zootecnia 67(3):837845.

Moi M, Nääs IDA, Caldara FR, Paz ICDL, Garcia RG, Cordeiro AF (2014) Vocalization data mining for estimating swine stress conditions. Engenharia Agrícola 34(3):445-450.
Nääs IA, Campos LSL, Baracho MS, Tolon YB (2008)

Uso de redes neurais artificiais na identificação de vocalização de suínos. Engenharia Agricola 28:204-216. DOI: http://dx.doi.org/10.1590/S010069162008000200001

Numberger J, Ritzmann M, Übel N, Eddicks M, Reese S, Zöls S (2016) Ear tagging in piglets: the cortisol response with and without analgesia in comparison with castration and tail docking. Animal 10:1864-1870. DOI: http://dx.doi.org/10.1017/S1751731116000811

Pandorfi H, Silva IJO, Sarnighausen VCR, Vieira FMC, Nascimento ST, Guiselini C (2011) Uso de redes neurais artificiais para predição de índices zootécnicos nas fases de gestação e maternidade na suinocultura. Revista Brasileira de Zootecnia 40:676-681. DOI: http://dx.doi.org/10.1590/S1516-35982011000300028

Rezende SO (2005) Sistemas Inteligentes: fundamentos e aplicações. São Paulo, Ed. Manole. 525p.

Risi N (2010) Uso da vocalização como indicador patológico em leitões na fase de maternidade. 93f. Dissertação Mestrado, Piracicaba, Universidade de São Paulo.

Schön PC, Puppe B, Manteuffel G (2001) Linear prediction coding analysis and self-organizing feature map as tools to classify stress calls of domestic pigs (Sus scrofa). Journal of Acoustics Society of America 110:1425-1431. DOI: http://dx.doi.org/10.1121/1.1388003

SI - Suinocultura Industrial (2017) Available in: https://www.suinoculturaindustrial.com.br/imprensa/asuinocultura-brasileira-e-as-tendenciasmundiais/20170718-163135-g289. Accessed: Aug 27, 2017.

Sobestiansky J, Wentz I, Silveira PRS, Sesti LAC (1998) Suinocultura Intensiva: produção, Manejo e Saúde do Rebanho. Brasília, EMBRAPA-SPI; Concórdia, EMBRAPA-CNPSa, 2ed. 388 p.

Tallet C, Linhart P, Policht R, Hammerschmidt K, Šmeček P (2013) Encoding of situations in the vocal repertoire of piglets (Sus scrofa): A comparison of discrete and graded classifications. PLOS ONE 8 (8): e71841. DOI: http://dx.doi.org/ 10.1371/journal.pone.0071841

Veloni M, Prado P, Arssuffi B, Ballestero M, Oliveira M, Abreu P, Oliveira L (2013) Bem-estar animal aplicado nas criações de suínos e suas implicações na saúde dos rebanhos. Revista Científica Eletrônica de Medicina Veterinária 21(1):1-21.

Weary DM, Braithwaite LA, Fraser D (1998) Vocal response to pain in piglets. Applied Animal Behaviour Science 56:161-172. DOI: http://dx.doi.org/10.1016/S0168-1591(97)00092-0

White RG, Deshazer JA, Tressler CJ, Borcher GM, Davey S, Waninge A, Parkhurst AM, Milanuk MJ, Clemens ET (1995) Vocalization and physiological response of pigs during castration with or without a local anesthetic. Journal of Animal Science 73:381-386. DOI: http://dx.doi.org/10.2527/1995.732381x 